\title{
ANGKA KEJADIAN BATU GINJAL DI RSUP PROF. DR. R. D. KANDOU MANADO PERIODE JANUARI 2010 - DESEMBER 2012
}

\author{
${ }^{1}$ Martha Elsy Banne Tondok \\ ${ }^{2}$ Alwin Monoarfa \\ ${ }^{2}$ Hilman Limpeleh
}

\author{
${ }^{1}$ Kandidat Skripsi Fakultas Kedokteran Universitas Sam Ratulangi Manado \\ ${ }^{2}$ Bagian Ilmu Bedah Fakultas Kedokteran Universitas Sam Ratulangi Manado \\ Email: elsy.bannetondok@yahoo.co.id
}

\begin{abstract}
Kidney stones or nephrolithiasis is condition where occures one or more stones in pelvis or calyces of kidney, this is the most problems in urinary tract. The cause of stones appeared wasn't accurately known but this disease can be varies attack populations in the world depend on their ages, sex, clan, geography locations and developed levels of a country.Purpose:The research is aimed to know incidence ofkidney stones in RSUP Prof. Dr. R. D. KandouManado January 2010-December 2012 periods, to know distributions explain depends on sex, age groups, stones position, complications, and any handles.Method: This research used descriptive retrospective methode by collecting data in the Section of Surgery and Medical Record department of RSUP Prof. Dr. R. D. KandouManado.Conclusion: The result of the research has showed that incidence of kidney stones in January 2010 until December 2012 was highest in 2012 (48,6\%) on 36-50 group of ages. The number of male patients was more common than female patients (3:2). Pyelum was location that always appeared the stones (85,7\%), and hydronephrosis has most complications (68,6\%). Patients always got pyelolithotomy for their handles $(34,3 \%)$.
\end{abstract}

Keywords : Incidence, kidney stones, Manado, nephrolithiasis

\begin{abstract}
Abstrak: Batu ginjal atau nefrolithiasis adalah suatu keadaan dimana terdapat satu atau lebih batu di dalam pelvisatau kaliksdari ginjal dan merupakan penyebab terbanyak kelainan di saluran kemih. Penyebab terbentuknya batu belum diketahui secara pasti, namun penyakit ini dapat menyerang penduduk di seluruh dunia dan bervariasi tergantung umur, jenis kelamin, ras, lokasi geografis dan tingkat kemajuan suatu bangsa. Tujuan: Penelitian ini bertujuan untuk mengetahui angka kejadian batu ginjal di RSUP Prof. Dr. R. D. Kandou Manado periode Januari 2010 - Desember 2012, serta mengetahui gambaran distribusi berdasarkan jenis kelamin, kelompok umur, letak batu, komplikasi, dan penanganan yang diberikan. Metode: Metode yang digunakan adalah metode deskriptif retrospektif, dengan mengumpulkan data di bagian Bedah dan bagian Rekam Medik RSUP Prof. Dr. R. D. Kandou Manado. Simpulan: Hasil penelitian menunjukkan bahwa angka kejadian batu ginjal selama periode Januari 2010 Desember 2012 tertinggi pada tahun 2012 (48,6\%) dan pada kelompok umur 36-50 tahun (48,6\%). Jumlah pasien laki-laki lebih banyak ditemukan daripada perempuan (3:2). Sedangkan lokasi tersering ditemukannya batu adalah di pielum (85,7\%), dan komplikasi terbanyak adalah hidronefrosis $(68,6 \%)$. Penanganan yang paling sering diberikan pada pasien adalah pielolitotomi (34,3\%).
\end{abstract}

Kata kunci : Angka kejadian, batu ginjal, Manado, nefrolithiasis 
Penyakit batu saluran kemih (BSK) merupakan penyakit umum yang masih menimbulkan beban kesehatan yang signifikan pada populasi usia kerja,dan merupakan tiga penyakit terbanyak di bidang urologi disamping infeksi saluran kemih dan pembesaran prostat benigna. ${ }^{1-3}$ Penyakit ini diduga sudah dikenal dan telah melanda manusia sejak catatan paling awal peradaban. ${ }^{2}$ Sebagai salah satu buktinya adalah ditemukan batu pada kandung kemih seorang mumi Mesir yang diperkirakan berumur sekitar 7000 tahun. ${ }^{3-5}$ Di Amerika Serikat 5$10 \%$ penduduknya menderita penyakit ini, sedangkan di seluruh dunia rata-rata terdapat $1-2 \%$ penduduk yang menderita batu saluran kemih. ${ }^{3} \mathrm{Di}$ Indonesia, penyakit BSK masih memegang andil terbesar dari total pasien di klinik urologi, dan kejadian yang tepat masih belum ditentukan. ${ }^{7}$

Menurut tempatnya, BSK digolongkan menjadi batu ginjal dan batu kandung kemih, tetapi batu ginjal merupakan penyebab terbanyak. Batu ginjal merupakan suatu keadaan dimana terdapat satu atau lebih batu di dalam pelvisatau kaliksdari ginjal. ${ }^{8,9}$ Secara garis besar pembentukan batu ginjal dipengaruhi olehfaktor intrinsik dan ekstrinsik.Faktor intrinsik yaitu umur, jenis kelamin, dan keturunan, sedangkan faktor ekstrinsik yaitu kondisi geografis, iklim, kebiasaan makan, zat yang terkandung dalam urin, dan sebagainya. ${ }^{3,9}$ Prevalensi seseorang mengalami batu ginjal sepanjang hidupnya diperkirakan bervariasi antara 115\%,dengan jumlah penderita laki-laki tiga kali lebih banyak dibandingkan dengan perempuan, dan umumnya didapatkan pada dekade ketiga sampai dekade kelima.,3,10

Penelitian epidemiologi memberi kesan seakan-akan penyakit batu mempunyai hubungan dengan tingkat kesejahteraan masyarakat dan berubah sesuai dengan perkembangan kehidupan suatu bangsa. ${ }^{4}$ Di rumah sakit di Amerika Serikat, kejadian batu ginjal dilaporkan sekitar 7-10 pasien untuk setiap 1000 pasien rumah sakit dan 7-21 pasien untuk setiap 10.000 orang dalam setahun.Di beberapa rumah sakit di Indonesia juga pernah dilaporkan jumlah pasien dengan batu ginjal. Di rumah sakit Dr. Kariadi Semarang tahun 1979 telah dirawat 166 pasien batu saluran kemih dan hampir keseluruhan pasien (99\%) datang dengan problem medis batu ginjal yang dilaporkan sebesar 35\%. Tahun 1981-1983 dilaporkan dari 634 pasien batu saluran kemih didapatkan 337 pasien batu ginjal (53\%). Sedangkan di rumah sakit Dr. Sardjito pada tahun 1983 dilaporkan 75\% batu ginjal dari 64 pasien rawat inap, dan pada tahun 1986 batu ginjal ditemukan 79 dari 89 pasien batu saluran kemih. ${ }^{8}$ Angka kejadian batu ginjal di Indonesia tahun 2002 berdasarkan data yang dikumpulkan dari rumah sakit di seluruh Indonesia adalah sebesar 37.636 kasus baru, dengan jumlah kunjungan sebesar 58.959 orang. Sedangkan jumlah pasien yang dirawat adalah sebesar 19.018 orang, dengan jumlah kematian adalah sebesar 378 orang. ${ }^{11}$

\section{METODE}

Penelitian ini bersifat deskriptif retrospektif dengan menggunakan data sekunder berupa catatan medik penderita, yang dilakukan di bagian Bedah dan bagian Rekam Medik RSUP Prof. Dr. R. D. Kandou Manado dan dilaksanakan pada November 2013 - Desember 2013. Subjek yang diteliti adalah semua pasien dengan diagnosis utama batu ginjal yang berobat di RSUP Prof. Dr. R. D. Kandou Manado selama periode Januari 2010 - Desember 2012.

Data yang dikumpulkan dari catatan medik yaitu umur, jenis kelamin, letak batu, komplikasi, dan penanganan yang diberikan. Selanjutnya dilakukan pengolahan data, analisis data, dan disajikan dalam bentuk laporan penelitian.

\section{HASIL}

Berdasarkan penelitian di RSUP Prof. Dr. R. D. Kandou Manado periode Januari 2010 Desember 2012, didapatkan sebanyak 99 penderita dengan diagnosa utama batu ginjal, namun 
data-data penderita yang ada dan lengka hanya 35.Dari 35 penderita, didapatkan 15 penderita (42,9\%) pada tahun 2010, 3 penderita (8,6\%) pada tahun 2011, dan 17 penderita (48,6\%) pada tahun 2012. (tabel 1)

Tabel 1. Distribusi kejadian batu ginjal berdasarkan tahun

\begin{tabular}{ccc}
\hline Tahun & $\mathbf{N}$ & $\mathbf{\%}$ \\
\hline 2010 & 15 & 42,8 \\
2011 & 3 & 8,6 \\
2012 & 17 & 48,6 \\
Total & $\mathbf{3 5}$ & $\mathbf{1 0 0 , 0}$ \\
\hline
\end{tabular}

\section{Jenis Kelamin}

Berdasarkan hasil penelitian, didapatkan jumlah penderita laki-laki sebanyak 21 penderita (60\%) dan perempuan sebanyak 14 penderita (40\%). (tabel 2)

Tabel 2. Distribusi penderita batu ginjal berdasarkan jenis kelamin

\begin{tabular}{ccc}
\hline Jenis Kelamin & n & \% \\
\hline laki-laki & 21 & 60,0 \\
perempuan & 14 & 40,0 \\
Total & 35 & $\mathbf{1 0 0 , 0}$ \\
\hline
\end{tabular}

\section{Umur}

Berdasarkan hasil penelitian, didapatkan jumlah penderita pada kelompok umur 21-35 tahun adalah 1 penderita (2,9\%),pada kelompok umur 36-50 tahun adalah 17 penderita (48,6\%), pada kelompok umur 51-65 tahun adalah 13 penderita (37,1\%), dan pada kelompok umur $>65$ tahun adalah 4 penderita $(11,4 \%)$. (tabel 3)

Tabel 3. Distribusi penderita batu ginjal berdasarkan umur

\begin{tabular}{ccc}
\hline Umur (tahun) & $\mathbf{n}$ & $\mathbf{\%}$ \\
\hline $21-35$ & 1 & 2,9 \\
$36-50$ & 17 & 48,6 \\
$51-65$ & 13 & 37,1 \\
$>65$ & 4 & 11,4 \\
Total & $\mathbf{3 5}$ & $\mathbf{1 0 0 , 0}$ \\
\hline
\end{tabular}




\section{Letak Batu}

Berdasarkan hasil penelitian, jumlah penderita dengan lokasi batu di pielum adalah 30 penderita (85,7\%), lokasi batu di kaliks adalah 2 penderita (5,7\%), dan lokasi batu di pelviokaliks adalah 3 penderita (8,6\%). (tabel 4)

Tabel 4. Distribusi penderita batu ginjal berdasarkan letak batu

\begin{tabular}{ccc}
\hline Letak & n & \% \\
\hline Pielum & 30 & 85.7 \\
Kaliks & 2 & 5.7 \\
Pelviokaliks & 3 & 8.6 \\
Total & $\mathbf{3 5}$ & $\mathbf{1 0 0 . 0}$ \\
\hline
\end{tabular}

\section{Komplikasi}

Berdasarkan hasil penelitian, jumlah penderita dengan komplikasi hidronefrosis adalah 24 penderita (68,6\%), sedangkan penderita tanpa komplikasi adalah 11 penderita $(31,4 \%)$. (tabel 5)

Tabel 5. Distribusi penderita batu ginjal berdasarkan komplikasi

\begin{tabular}{ccc}
\hline Komplikasi & $\mathrm{n}$ & $\%$ \\
\hline Hidronefrosis & 24 & 68.6 \\
Tidak ada & 11 & 31.4 \\
Total & $\mathbf{3 5}$ & $\mathbf{1 0 0 . 0}$ \\
\hline
\end{tabular}

\section{Penanganan}

Berdasarkan hasil penelitian, jumlahpenderita yang mendapat penanganan dengan pielolitotomi adalah 12 penderita (34,3\%), penanganan dengan extended pielolitotomi adalah 5 penderita (14,3\%), penanganan dengan ESWL adalah 1 penderita (2,9\%), penanganan dengan bivalve adalah 2 penderita(5,7\%), dan yang tidak mendapat penanganan adalah 15 penderita (42,8\%). (tabel 6)

Tabel 6. Distribusi penderita batu ginja berdasarkan penanganan

\begin{tabular}{ccc}
\hline Penanganan & $\mathbf{n}$ & $\mathbf{\%}$ \\
\hline Pyelolithotomy & 12 & 34,3 \\
Extended Pyelolithotomy & 5 & 14,3 \\
ESWL & 1 & 2,9 \\
Bivalve & 2 & 5,7 \\
Tidak ada & 15 & 42,8 \\
Total Data & $\mathbf{3 5}$ & $\mathbf{1 0 0 , 0}$ \\
\hline
\end{tabular}




\section{BAHASAN}

Berdasarkan hasil penelitianpada tabel 1 ditunjukkan bahwa dari 35 penderita batu ginjal, kejadian terbanyak terjadi pada tahun 2012 yaitu sebanyak 17 penderita (48,6\%), dan paling sedikit pada tahun 2011 yaitu sebanyak 3 penderita (8,6\%). Angka kejadian penyakit ini tidak sama diseluruh belahan bumi. Penelitian epidemiologi memberi kesan seakan-akan penyakit ini berhubungan dengan tingkat kesejahteraan masyarakat dan perkembangan kehidupan suatu bangsa. Di negara maju lebih banyak dijumpai, karena adanya pengaruh status gizi dan aktivitas pasien sehari-hari. ${ }^{3,4}$ Hal ini juga tergantung pada faktor geografi serta iklim dan temperatur dari suatu daerah. Pada beberapa daerah menunjukkan angka kejadian yang lebih tinggi daripada daerah lain sehingga dikenal sebagai daerah stone belt. Begitu juga dengan individu yang menetap di daerah beriklim panas dengan paparan ultraviolet tinggi akan cenderung mengalami dehidrasi serta peningkatan produksi vitamin D (memicu peningkatan ekskresi kalsium dan oksalat) serta menyebabkan pengeluaran keringat yang banyak sehingga mengurangi produksi urin. ${ }^{3}$

Distribusi penderita batu ginjal berdasarkan jenis kelamin pada tabel 2 menunjukkan bahwa jumlah penderita laki-laki lebih banyak daripada perempuan.Yaitu dengan perandingan 3:2. Penelitian Aries Alpendri di RS Dr. Sardjito juga menemukan dari 59 penderita batu ginjal, terdapat 32 laki-laki dan 57 perempuan. ${ }^{12}$ Penelitian ini sesuai dengan kepustakaan yang menyatakankan bahwa batu ginjal lebih banyak diderita oleh laki-laki,dengan angka kejadian 3 kali lebih banyak daripada perempuan. ${ }^{3,10}$ Hal ini karena kadar kalsium air kemih sebagai bahan utama pembentuk batu lebih rendah pada perempuan daripada laki-laki, dan kadar sitrat air kemih sebagai bahan penghambat terjadinya batu pada perempuan lebih tinggi daripada laki-laki. ${ }^{13}$ Selain itu, hormon estrogen pada perempuan mampu mencegah agregasi garam kalsium,sedangkan hormon testosteron yang tinggi pada laki-laki menyebabkan peningkatan oksalat endogen oleh hati yang selanjutnya memudahkan terjadinya kristalisasi. ${ }^{13,14}$

Distribusi penderita batu ginjal pada tabel 3 menunjukkan bahwa umur yang paling banyak menderita batu ginjal adalahkelompok umur 36-50 tahun, dan paling sedikit pada kelompok umur 21-35 tahun adalah 2,9\%. Penelitian sebelumnya yang dilakukan oleh Aries Alpendri di RS dr. Sardjito menemukan bahwa umur terbanyak yang menderita batu ginjal adalah kelompok umur 40-59 tahun pada laki-laki dan kelompok umur 40-59 tahun pada perempuan. ${ }^{12}$ Penelitian ini sejalan dengan kepustakaan yang menyatakan bahwa penyakit ini umumnya didapatkan pada dekade ketiga sampai dekade kelima. ${ }^{3,10}$ Dengan bertambahnya umur menyebabkan gangguan peredaran darah seperti hipertensi dan kolesterol tinggi. Hipertensi dapat menyebabkan pengapuran ginjal yang dapat berubah menjadi batu, sedangkan kolesterol tinggi merangsang agregasi dengan kristal kalsium oksalat dan kalsium fosfat sehingga mempermudah terbentuknya batu. ${ }^{13}$

Berdasarkan anatomi dari ginjal, lokasi batu ginjal biasanya dijumpai khas di dalam pelvis (pielum) dan kaliks. Batu pielum didapatkan dalam bentuk yang sederhana sehingga hanya menempati bagian pelvis, tetapi dapat juga tumbuh mengikuti bentuk susunan pelviokaliks sehingga bercabang menyerupai tanduk rusa (batu staghorn). ${ }^{4}$ Dari hasil penelitian pada tabel 4, menunjukkan bahwa batu ginjal lebih banyak terletak pada pielumyaitu 30 penderita (85,7\%),kemudian di dalam pelviokaliks yaitu 3 penerita $(8,6 \%)$, dan paling sedikit di dalam kaliks yaitu 2 penderita (5,7\%). Hal ini sesuai dengan kepustakaan yang menyatakan bahwa batu biasanya terletak di dalam pelvis ginjal, dan tempat terbanyak berikutnya adalah di kaliks. ${ }^{15}$ Berdasarkan anatomi dari ginjal, sebelum memasuki ureter terdapat penyempitan (diameter berkurang 2-3 mm) di uretero-pelvic junction yaitu tempat pertemuan pelvis ginjal dengan ureter. Secara umum, batu yang berukuran kecil dengan diameter maksimum 4-5 mm akan mampu melewati ureter dan biasanya keluar bersama urine, sedangkan batu yang berukuran lebih besar akan tersangkut di pelvis ginjal yang 
menyebabkan obstruksi dan menjadi penyebab terjadinya hidronefrosis bahkan kerusakan dari ginjal. $^{10,15}$

Pada tabel 5, menunjukkan bahwa komplikasi yang paling sering terjadi akibat penyakit batu ginjal adalah hidronefrosis yaitu sebanyak 24 penderita (68,6\%), sedangkan 11 penderita $(31,4 \%)$ tidak terdapat komplikasi. Hidronefrosis terbagi menjadi 4 grade yaitu grade I, grade II, grade III dan grade IV. Pada penelitian ini telah didapatkan bahwa letak batu terbanyak adalah di pielum. Hal ini berhubungan dengan kepustakaan yang menyatakan bahwa sesuai dengan gangguan yang terjadi, batu ginjal yang terletak di pelvis (pielum) dapat menyebabkan terjadinya hidronefrosis sebagai akibat dari obstruksi, sedangkan batu di kaliks dapat menimbulkan kaliektasis pada kaliks yang bersangkutan. ${ }^{4}$

Pada tabel 6menunjukkan bahwa penanganan yang paling sering diberikan pada penderita adalah pielolithotomi yaitu sebanyak 12 penderita (34,3\%). Terdapat juga 15 penderita (42,8\%) yang tidak mendapatkan penanganan, dengan beberapa alasan yaitu penderita/keluarga menolak tindakan, data penderita tidak lengkap, atau tidak memungkinkan untuk dilakukan penanganan.

Penelitian ini menggunakan data sekunder berupa catatan medik pasien. Penelitian dengan menggunakan data sekunder terkadang kurang akurat karena terdapat beberapa data pasien yang kurang lengkap, sehingga data tersebut dianggap sebagai missing case dan tidak bisa diikutsertakan dalam penelitian. Selain itu juga terdapat beberapa data yang sudah tidak ada atau belum di bawa ke bagian Rekam Medis sehingga data yang didapatkan sangat terbatas, khususnya pada tahun 2011.

\section{SIMPULAN}

Berdasarkan hasil penelitian yang dilakukan selama periode Januari 2010 - Desember 2012 dapat disimpulkan bahwa kejadiantertinggi batu ginjal terjadi pada tahun 2012 dan pada kelompok umur 36-50 tahun. Penderita laki-laki lebih banyak ditemukan daripada perempuan, yaitu dengan perbandingan 3:2.

Pielum menjadi lokasi tersering ditemukannya batu, dan komplikasi terbanyak yang diakibatkan adalah hidronefrosis. Sedangkan penanganan yang paling sering diberikan pada penderita batu ginjal adalah pielolitotomi.

\section{SARAN}

Masyarakat sebaiknya lebih memperhatikan dan merubah gaya hidup untuk mencegah terbentuknya batu pada ginjal, khususnya untuk kelompok yang rentan dan juga penanganan sebaiknya dilakukan sedini mungkin untuk mencegah terjadinya komplikasi yang lebih berat di kemudian hari.

\section{UCAPAN TERIMA KASIH}

Ucapan terima kasih ditujukan kepada dr. Ainun Aschorijanto, SpU dan dr. Victor Pontoh, $\mathrm{SpB}(\mathrm{K})$ Onk, selaku penguji skripsi, dan semua pihak yang baik secara langsung maupun tidak langsung yang telah menumbuhkan idea dan gagasan pada penulis.

\section{RUJUKAN}

1. Hanley JM, Saigal CS, Scales CD, Smith AC,. Prevalences of Kidney Stone in the United States. Journal European Association of Urology. 2012;62:160. 
2. Bolton DM, Stoller ML. Urinary Stone Disease. In: McAninch JW , Tanagho EA, editors. Smiths General Urology. Ed 14. USA: Appleton and Lange; 1995. p.276-286.

3. Purnomo Basuki B. Dasar Dasar Urologi. Ed 2. Jakarta: Sagung Seto; 2003. h.57-66.

4. Achmad IA (alm), Bowolaksono,Manuputty David, Sukasah CL, Swantari NM,Umbas Rainy, et al. Saluran Kemih dan Alat Kelamin Lelaki. Dalam: Karnadihardja W, Prasetyono TOH, Rudiman R, Sjamsuhidajat R, editor. Buku Ajar Ilmu Bedah. Jakarta: EGC; 2010. h.850-77.

5. Syahputra FA. Terapi Batu Ginjal: Dari Era Hippocrates ke Era Minimal Invasif. The Journal of the Indonesian Medical Association. 2011;61:99-100.

6. Munim A, Shah N, Siddiqui EH, Siddiqui S. Urolithiasis: Presentation and Ultrasonographic Evaluation. Professional Med J. 2011;18(3):380.

7. Prasadja N, Soebadi DM, Soesanto WD, Widodo JP. Stone-Free Rate Differences in Kidney Stones Patient With and Without Tamsulosin After ESWL. Indonesian Journal of Urology. 2011;18(2):36.

8. Sja’bani M. Batu Saluran Kemih. Dalam: Alwi IK, Marchellus S, Setiati S, Setiyohadi B, Sudoyo AW, editor. Buku Ajar Ilmu Penyakit Dalam. Ed 5. Jakarta: InternaPublishing; 2009. h.1025-30.

9. Krisna DNP. Faktor Resiko Kejadian Penyakit Batu Ginjal di Wilayah Kerja Puskesmas Margasari Tegal. Juli 2011 [cited September 2013].Availaible from: http://journal.unnes.ac.id/index.php/kemas

10. Drach GW. Urinary Lithiasis. In: Gitters, Harrison, Perlmutter, Stamey, Walsh. Campbell's Urology vol 1. $4^{\text {th }}$ Ed. London: W. B. Saunders Company; 1978. p.783-802.

11. Adioka, Adrianta, Alit-Widhiartini, Ernawati, Widana. Dose and Safety of Hypoetes Polythyrsa Miq Ethanol Extract For Dissolving Renal Calculi: an affordable medication. Indonesia Journal of Biomedical sciences. 2012;6(2):51.

12. Alpendri A, Danarto HR. Stone Composition Pattern of Kidney Stone. Indonesian Journal of Urology. 2013;20(1):34-6.

13. Lina N. Faktor-faktor Resiko Kejadian Batu Saluran Kemih pada Laki-laki (Studi Kasus di RS Dr. Kariadi, RS Roemani dan RSI Sultan Agung Semarang) [Tesis]. Semarang: Universitas Diponegoro; 2008.

14. Syafrina I. Karakteristik Penderita Batu Saluran Kemih Rawat Inap di Rumah Sakit Haji Medan Tahun 2005-2007 [Skripsi]. Medan: Universitas Sumatera Utara; 2008.

15. Awari N, Bayley A, Beasley A, Boland J, Crawford M, Driessen F, et al. Urology: Stones In The Urinary Tract. In: King M, Bewes P, Cairns J, Thornton J, editors. Primary Surgery. Jena: 1999 [cited 2014 February].Available from:http://www.meb.unibonn.de/dtc/primsurg/ 